\title{
Tip 1 Diyabet ve Çölyak Hastalığı Birlikteliği: Olgu Sunumu
}

\author{
Type 1 Diabetes and Celiac Disease Coexist: Case Report
}

Yasemin Atik Altınok ${ }^{1}$, Damla Gökşen ${ }^{2}$

Geliş tarihi/Received: 21.11.2020 • Kabul tarihi/Accepted: 29.12.2020

\section{ÖZET}

Tip 1 diyabet ve çölyak hastalığı en yaygın pediatrik otoimmün hastalıklardır. Tip 1 diyabetli çocuk ve ergenlerde çölyak hastalığı sıklığı genel popülasyondan daha yüksektir. Tip 1 diyabetli çocuklarda çölyak hastalığının genellikle asemptomatik olması nedeniyle, çoğu olgu yalnızca çölyak hastalığı taraması ile tanı alır. Glutensiz diyet tek tedavi yöntemidir. İyi metabolik kontrol ve büyümenin devamını sağlamak için aileye/bakımdan sorumlu bireylere yeterli-dengeli glutensiz diyet uygulamaları ve karbonhidrat sayımı konularında danışmanlık bu konuda deneyimli diyetisyen tarafından verilmelidir. Bu makalede, tip 1 diyabet ve çölyak hastalığı olan olgu sunulmuştur.

Anahtar kelimeler: Tip 1 diyabet, çölyak hastalı̆̆l, glutensiz diyet

\section{ABSTRACT}

Type 1 diabetes and celiac disease are the most common pediatric autoimmune diseases. The prevalence of celiac disease in children and adolescents with type 1 diabetes is higher than in the general population. Since celiac disease is usually asymptomatic in children with type 1 diabetes, most cases are only diagnosed by celiac disease screening. A gluten-free diet is the only treatment method. Family/caregivers should receive dietary counselling on gluten-free dietary practices and carbohydrate counting to ensure good metabolic control and maintenance of growth, by an experienced dietitian. In this article, a case with Type 1 diabetes and celiac disease is presented.

Keywords: Type 1 diabetes, celiac disease, gluten-free diet

\section{Gíriş}

Çölyak hastalığı ve tip 1 diyabet ortak genetik varyantları paylaşan, her ikisi de kronik olan otoimmün hastalıklardır ve diğer otoimmün hastalıklara benzer şekilde her iki hastalığın da oluşumunda genetik duyarlılık ve çevresel faktörlerin birlikteliği rol oynar (1). Üç kıtada 53.000 tip 1 diyabetli

\footnotetext{
1. İletişim/Correspondence: Ege Üniversitesi Tıp Fakültesi Pediatrik Endokrinoloji BD, İzmir, Türkiye

E-posta: yaseminatik@yahoo.com.tr • 이 https://orcid.org/0000-0001-5851-1012
}

çocuk ve ergenle yapılan uluslararası bir araştırmada, biyopsi ile doğrulanmış çölyak hastalığı prevalansı \%3.5 olarak bildirilmiş ve ülkeler arasında önemli farklılıklar olduğu ortaya konmuştur. Buna göre çölyak prevalansı Amerika Birleşik Devletleri'nde \%1.9 iken Avustralya'da \%7.7’ye yükselmektedir (2).

2. Ege Üniversitesi Tıp Fakültesi Pediatrik Endokrinoloji BD, İzmir, Türkiye (1) https://orcid.org/0000-0001-6108-0591 
Ülkemizde Gökşen ve ark.'nın (3) araştırma sonucuna göre tip 1 diyabetli çocuk ve ergenlerde çölyak hastalığı prevelansı \%4.3’tür.

Çölyak hastalığı riski, diyabetin tanı yaşıyla negatif ve bağımsız şekilde korelasyon gösterir ve en riskli grubu beş yaşından önce tanı alan diyabetli çocuklar oluşturur. Tip 1 diyabetlilerde çölyak hastalığı genellikle asemptomatiktir ve büyüme hızında azalma, glisemik kontrolde bozulma veya sık hipoglisemi ile mutlak ilişkisi yoktur ancak bu tür durumlarda varlığının dışlanması gereklidir (4). Kronik veya aralıklı ishal ve/veya kabızlık, kronik karın ağrısı/kramp, şişkinlik, iştahsızlık, dispeptik semptomlar ile tekrarlayan hipoglisemi, anemi, açıklanamayan yetersiz büyüme, vücut ağırlık kaybı veya tekrarlayan aftöz ülserasyonlar da dahil olmak üzere gastrointestinal belirti veya semptomları olan tip 1 diyabetli çocuk ve ergenlerde çölyak hastalığının varlığı değerlendirilmelidir (5).

Tip 1 diyabet ve çölyak hastalığı süreçlerinin ne zaman başlayacağı ve tüm tip 1 diyabetlilerde çölyak hastalığı için tarama yapılmasının gerekliliği hakkında birçok cevaplanmamış soru olmakla birlikte Uluslararası Çocuk ve Adolesan Diyabet Derneği (International Society of Pediatric and Adolescent Diabetes, ISPAD), tüm tip 1 diyabetlilerin tanı anında ve diyabetin en az 2-5. yılları arasında taranmasını; eğer diyabetlinin semptomları varsa veya birinci derece yakınında çölyak hastalığı mevcutsa taramanın daha önce yapılmasını önermiştir (4).

Çölyak hastalığı taramasında, immünoglobulin A (IgA) doku transglutaminaz ve/veya endomisyal antikorları kullanılır. Her ikisinin de duyarlılık ve özgüllüğü \%90’nın üzerindedir (6). IgA eksikliği bulunan diyabetlilerde, çölyak hastalığı taraması immünoglobulin G (IgG)'ye özgü antikor testleri kullanılarak yapılmalıdır. Tarama testi sonucunda antikor seviyesi yükselmiş diyabetliye, ince bağırsak Marsh Sinıflaması'na göre subtotal villus atrofisi varlığının değerlendirilmesi ve çölyak hastalığı tanısının doğrulanması için biyopsi yapılması gereklidir (4).
Günümüzde çölyak hastalığının tedavisinde 'glutensiz diyet' halen kabul görmüş tek seçenektir. Glutensiz diyet; buğday, çavdar, arpa, tritikale gibi tahlllar ve bunlardan elde edilen ürünlerin yerine; mısır, pirinç, darı, sorgum, tef gibi glutensiz tahılların; karabuğday, amarant, psilium, kinoa gibi psödo tahılların ve patates, kurubaklagiller gibi nişastalı besinlerin kullanıldığı ömür boyu süren bir eliminasyon diyetidir. Glutensiz diyette yulaf çoğu diyabetli tarafindan tolere edilirken, az sayıda diyabetlinin yulafa karşı reaksiyon geliştirdiğine dair veriler mevcuttur. Yulafin gluten içeren besinlerle kontaminasyonu endişe uyandırdığından 'glutensiz' olarak etiketlendirilmemiş yulafin kullanımı önerilmemektedir (7). Glutensiz diyet besleyici değeri yüksek doğal glutensiz besinler ile dengelenmezse ve sadece ticari özel ürünlere dayandırılırsa diyetle karbonhidrat ve yağ alımı artarken, protein, vitamin, mineral ve diyet posası alımı yetersiz kalabilir (8). Bunun yanı sira glutensiz diyetin örüntüsü, glisemik yanıtın kontrolünde de bazı sorunlara yol açabilmektedir (9). Glutensiz ürünler, geleneksel olarak rafine edilmiş bazı unlar (pirinç ve mısır unu gibi) ve nişastalar (mısır, patates nişastası gibi) ile hazırlanır ve bu tür ürünlerin glisemik indeks değeri yüksektir (10). Bunların yerine besin değeri yüksek alternatif hammaddelerin (glutensiz tahıl, psödotahıl, kurubaklagil ve olgunlaşmamış muz unları gibi) kullanımı, elde edilen ürünün diyet posası, protein ve dirençli nişasta miktarını artırarak glisemik indeksinin azalmasını sağlar (8). Bunlara ek olarak eklenen posa, protein ve yağ, ekşi maya fermantasyonu, çoklu tahıl formülasyonu elde edilen ürünün glisemik indeksinin klasik formülasyona göre daha düşük olmasını sağlar (10). Tip 1 diyabet ve çölyak hastalığı birlikteliği, glutensiz diyete uyum sağlamak, karbonhidrat alımını devamlı kontrol etmesi gereken diyabetli çocuk ve ergenlerin hayatlarında ek zorluk oluşturur. Glutensiz diyete uyum, metabolik kontrolü iyileştirebilir ve büyümenin devamını sağlarken; diyete uyumsuzluk diyabetik bireyi hipoglisemiye yatkın hale getirir ve yaşam kalitesini düşürür $(11,12)$. 


\section{OLGU SUNUMU}

Dört yaş bir aylık iken diyabetik ketoasidoz tablosu ile başvurduğu dış merkezde tip 1 diyabet tanısı alan kız olgu, diyabet yaşı 10 ay iken sık hipoglisemi şikayetiyle kliniğimize başvurmuştur ve kan şekeri regülasyonu, diyabet bakımı eğitimi planlanarak kliniğimize yatışı yapılmıştır. Olgunun antropometrik ölçümleri Neyzi 2008 büyüme eğrilerine göre değerlendirilmiştir (13). Olgunun başvuru sırasında vücut ağırlığı:18.5 kg (yaşa göre -0.07 SD), boy uzunluğu: $106.4 \mathrm{~cm}$ (yaşa göre -0.59 SD), beden kütle indeksi (BKİ): $16.34 \mathrm{~kg} / \mathrm{m}^{2}$ (yaşa göre 0.58 SD), HbA1c: \%7.2 olarak kaydedilmiştir. Yapılan göz bakısı olağan, kemik yaşı olgunun yaşı ile uyumlu, böbrek ve karaciğer fonksiyon testleri, kan lipit profili normal olarak değerlendirilmiştir, ancak serum ferritin düzeyinin (6 ng/mL) referans düzeyin (13-150 $\mathrm{ng} / \mathrm{mL}$ ) altında olduğu tespit edilmiştir.

Yaşına uygun enerji ve makro besin ögesi içeren beslenme programı düzenlenen olguya sağlıklı beslenme, besin ögeleri, besin grupları, besinlerin kan şekerine etkisi, besin-insülin ilişkisi, değişim sistemi, posa ve glisemik indeks gibi konu başlıklarını içeren beslenme eğitimi ve diyabet bakımı eğitimi verilmiştir. Ayrıca serum ferritin düşüklüğü nedeniyle $6 \mathrm{mg} / \mathrm{kg}$ demir desteği başlanarak taburcu edilmiştir. İki ay sonraki kontrolünde serum ferritin düzeyi 7.7 ng/mL’ye yükselen, diyabet yaşı 1 yıl 4 ay olan olguya demir yetersizliği nedeniyle çölyak tarama testi yapıldığında IgA anti-gliadin değerinin 119 U (normal düzey <10 U) ve IgA anti-endomisyal değerinin $500 \mathrm{U}$ (normal düzey <20 U) olduğu gözlenmiş ve pediatrik gastroenteroloji kliniğine yönlendirilmiştir. Yapılan ince bağırsak biyopsisi sonucuna göre kronik antral gastrit ve kronik özafajit tanısı alan ve çölyak hastalığı tam olarak ekarte edilemeyen olguya tıbbi tedavi düzenlenmiştir. İki ay sonra yapllan incebağırsak biyopsisinde bulbus ve duodenumdan alınan örneklerde villus arşitektürde küntleşme ve yer yer subtotal villus atrofisine varan değişiklikler saptanması ile olgu çölyak hastalığı tanısı almıştır.

Tip 1 diyabet ve çölyak hastalığı birlikteliği olan olgunun Tip 1 diyabete özgü beslenme programından gluten içeren besinler elimine edilmiştir. Yoğun insülin tedavisi alan (0.68 U insülin/kg; \%42 bazal, \%58 bolus insülin) ve yaşına göre BKİ SD skoru 0.58 olan olguya 1500 kkal/gün enerji içeren (enerji dağılımı: \%52 karbonhidrat, \%18 protein, \%30 yağ), glisemik indeksi düşük beslenme önerilerini içeren beslenme programı düzenlenmiştir. Olgunun ebeveynlerine besin değeri yüksek glutensiz karbonhidrat kaynakları, gluten bulaş yolları, besin dışı gluten kaynakları, ev dışında glutensiz beslenme vb. konuları içeren glutensiz diyete yönelik beslenme eğitimi verilmiştir.

Üç aylık poliklinik kontrolleri ile takibine devam edilen olgunun karbonhidrat sayımı eğitim süreci tamamlanmıştır. Bir haftalık besin tüketim kayıtları ve kan şekeri, fiziksel aktivite günlükleri gözden geçirilerek karbonhidrat/insülin oranı kahvaltı öğünü için 12, öğle ve akşam öğünleriiçin 50; insülin duyarlılık faktörü 120 olarak belirlenmiştir. Karbonhidrat sayımı uygulamasına başladıktan sonraki 1., 2., ve 4 . haftalarda olgu poliklinik kontrollerine çağrılarak, karbonhidrat sayımı uygulamalarının doğruluğu ve glutensiz diyete uyumu gözden geçirilmiştir.

Glutensiz diyet tedavisinin 1. yllında hastanın boy uzunluğundaki artış yeterli olarak değerlendirilmiştir $(+5 \mathrm{~cm} / \mathrm{yll})$. IgA anti-endomisyal değeri geriledi $(<10$ $\mathrm{U})$, son 6 ayda demir desteği almadığı halde serum ferritin değeri $48 \mathrm{ng} / \mathrm{dL}$, transferin satürasyonu $\% 10$, serum demir düzeyi düşük olmakla birlikte demir bağlama kapasitesi ve transferrin değeri normal sinırlarda gözlenmiştir. Glutensiz diyetin ikinci yılında yapılan ince bağırsak biyopsi sonucu normal olarak değerlendirilmiştir.

Okul öncesi dönemde tip 1 diyabet ve çölyak hastalığı tanısı alan olgunun ebeveynlerinin kontrolünde olduğu süreçte glutensiz diyete uyumu iyi ve IgA anti gliadin değerleri referans aralıkta izlenirken, olgunun okul yaşamına başlaması ile birlikte glutensiz diyete uyumun azaldığı ve IgA anti-gliadin değerlerinin yükseldiği gözlenmiştir (Şekil 1). $\mathrm{Bu}$ dönemde olguya yönelik yaşına uygun beslenme eğitimleri düzenlenerek ve ailenin hem karbonhidrat sayımı uygulama becerisi hem de glutensiz diyet hakkındaki 
bilgi düzeyi gözden geçirilerek olgunun diyete uyumu artırılmaya çalışılmıştır. Olgunun 8 ylllık izlem süresince ortalama HbA1c’si \%7.53 \pm 0.65 idi (Şekil 2).

Olgu glutensiz diyet başlangıcında 50. persentil değerinde olan yaşa göre vücut ağırlığı, 4 yıl süresince 25-50. persentil aralığında, sonraki süreçte 50-75. persentil aralığında izlenmiştir. Çölyak hastalığı tanısından önce 10. persentilde olan yaşa göre boy uzunluğu da, glutensiz diyet tedavisinin ilk yılında 25 . persentile ulaşmış ve tedavinin 5. yılından itibaren 25-50. persentil aralığında yer almıştır.

Olgunun büyüme eğrileri Şekil 3’te sunulmuştur.

\section{TARTIŞMA}

Tip 1 diyabetli çocuk ve ergenlerde çölyak hastalığ görülme sıklığı genel popülasyondan daha sıktır ve genellikle diyabetten sonra teşhis edilir. Tip 1 diyabet ve çölyak hastalığı birlikteliği asemptomatik olabilir ve kızlarda, erken yaşta Tip 1 diyabet tanısı alanlarda daha yaygındır (7). Tip 1 diyabetli çocuk ve ergenlerde çölyak hastalığı yetersiz büyüme, ergenliğin gecikmesi, beslenme yetersizlikleri, düşük kemik yoğunluğu, hipoglisemi ve hiperglisemi ile ilişkilendirilmiştir (9).

Her iki hastalık da çocukluk ve ergenlik döneminde düzenli izlem gerektirir. Tip 1 diyabet için, tedaviye uyum, insülin tedavisi ve glisemik kontrolün klinik değerlendirmesi genellikle üç ayda bir yapılır. Çölyak hastalığı olan diyabetlilerin izlemi daha bireyseldir ve diyabetli ile ailesinin/bakımdan sorumlu bireylerin diyet tedavisine uyum sağlama becerisine dayanır. Genel olarak, takip sıklığının glutensiz diyet tedavisine klinik ve serolojik yanıtı değerlendirmek için başlangıçta 3-6 ay ara ile ve sonrasında yıllık olması önerilmektedir. Bununla birlikte, özellikle ergenlik çağında beslenme tedavisine uyumla ilgili zorluklar ortaya çıkabilir ve bu nedenle, izlem planı esnek olmalı ve olguya göre uyarlanmalıdır. Olgumuzda diyabet izlem sıklığı 3 ay olarak planlandı, bununla birlikte diyabet ekibine istediği zaman ulaşabileceği telefon numaraları, e-posta adresleri verilerek ve istekleri dahilinde ara randevular planlanarak, besin tüketim kayıtları, kan şekeri ve fiziksel aktivite günlükleri aile/olgu ile birlikte değerlendirildi. Diyetinde metabolik kontrolü ve diyet kalitesini olumsuz etkileyen faktörler belirlenerek, düzeltilmesi

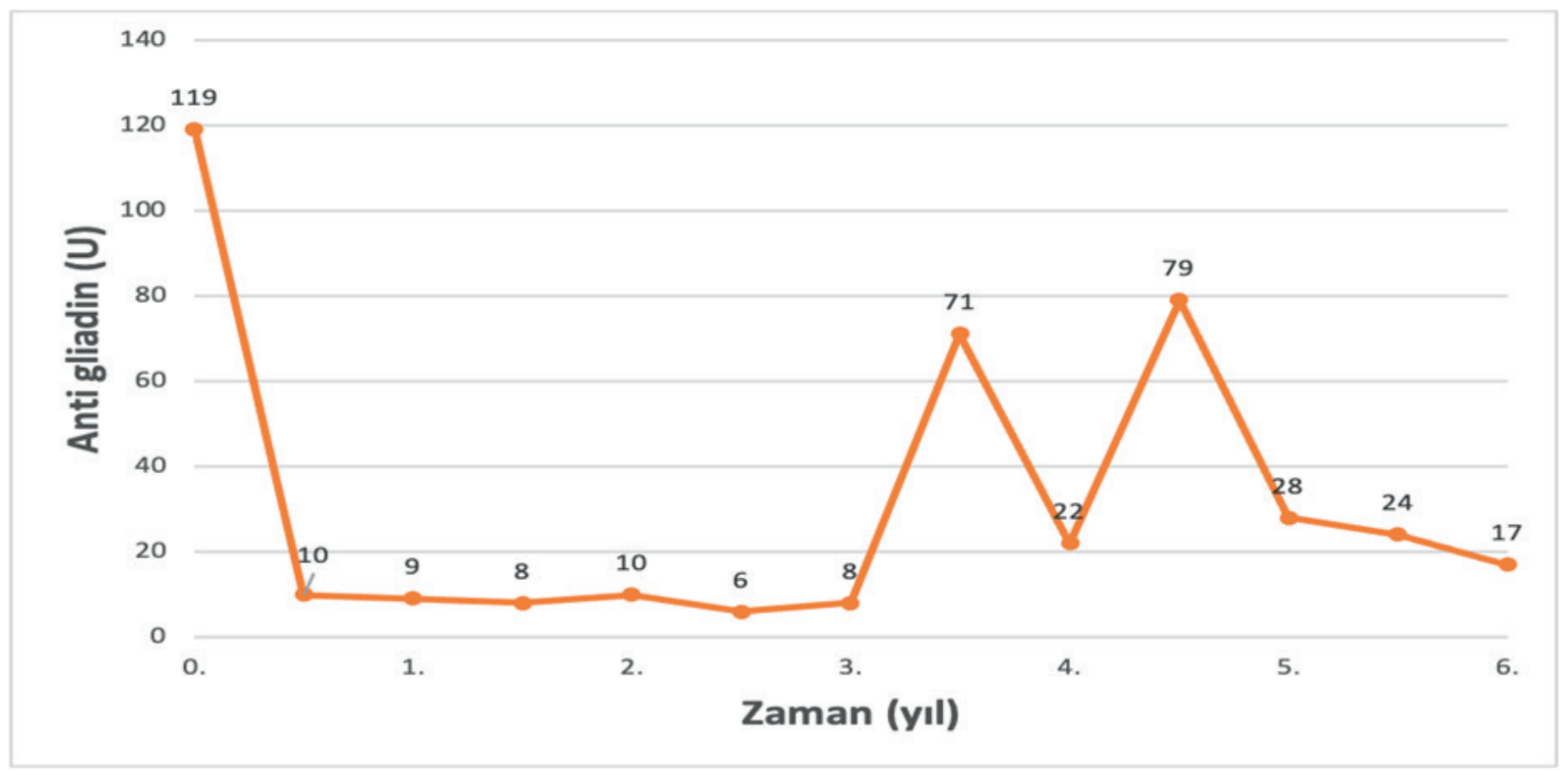

Şekil 1. İzlemde olgunun anti gliadin (U) değerleri 


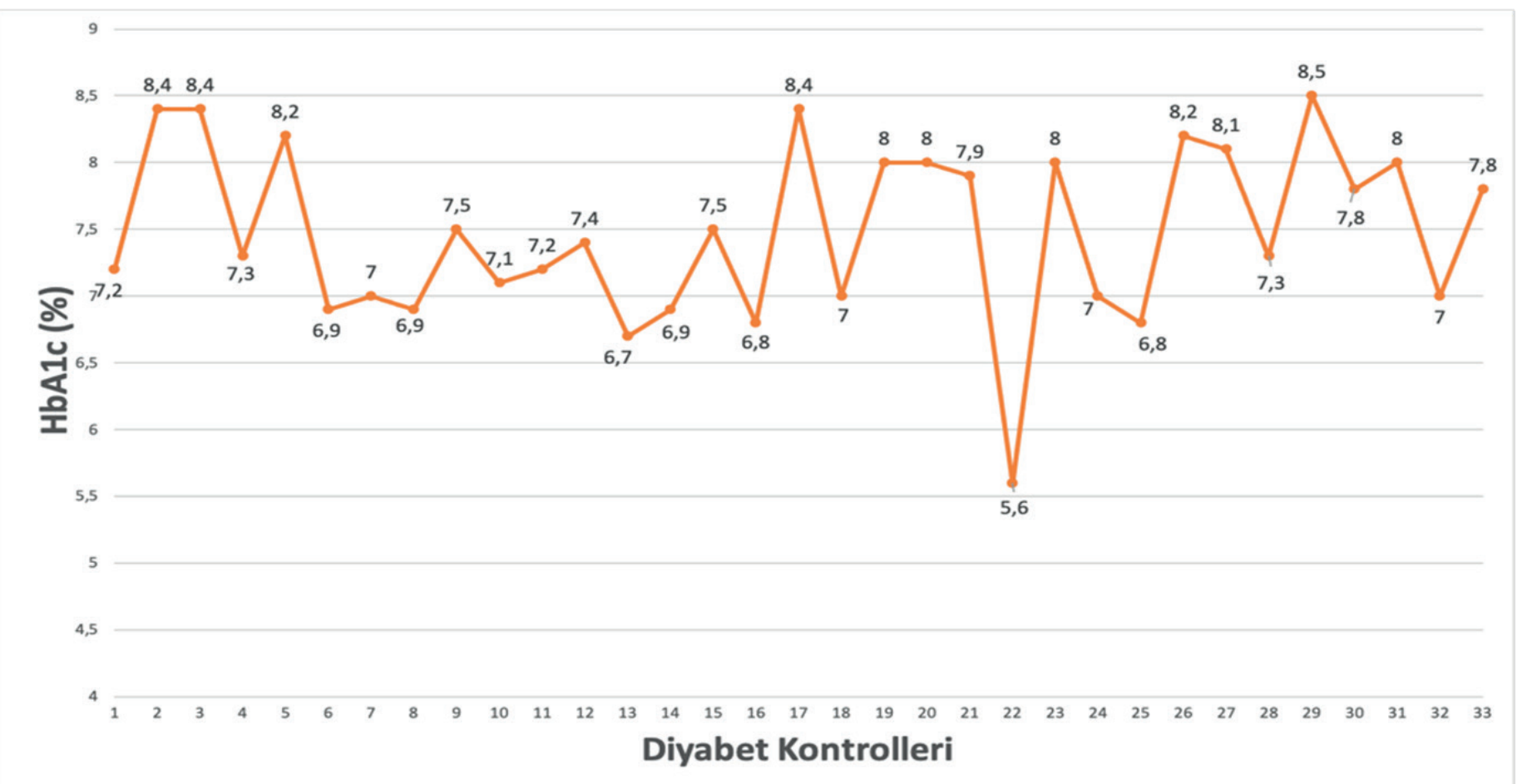

Şekil 2. İzlemde olgunun HbA1c (\%) değerleri

için gerekli bilgilendirmeler yapıldı. Tip 1 diyabet ve çölyak hastalığı birlikteliği olan olguların takibi; pediatrik endokrinolog, pediatrik gastroenterolog ve hem çocukluk çağı Tip 1 diyabeti hem de glutensiz diyet konusunda deneyimli diyetisyen arasında etkili bir ekip çalışması gerektirir (1).

Glutensiz diyette, tüketimine izin verilen veya kaçınılması gereken besinlere ilişkin tavsiyelere ek olarak, glutensiz diyetin besin değeri, özellikle de demir, kalsiyum, posa ve B vitamini alımlarına vurgu yapılmalıdır (7).

Tip 1 diyabetli çocuk ve ergenlerde ek tanı, çocuğun yaşam kalitesi üzerinde minimum etki gösterebilir iken glutensiz diyete uyumsuzluk yaşam kalitesini ve metabolik kontrolü olumsuz yönde etkileyebilir (11). Kötü metabolik kontrol de çocuklarda büyümeyi yavaşlatarak ve hedef boy uzunluğuna ulaşmayı güçleştirebilir. Glutensiz diyet tedavisinin başlangıcında 10. persentil değerinde olan yaşa göre boy uzunluğu ilk yllın sonunda 25. persentil değerine ulaşmıştır. Olgunun anne ve babasının boy uzunlukları ile hesaplanan hedef boyu 75. persentilde bulunmasına rağmen; tedavinin 4 . yılından itibaren hem ailenin/çocuğun beyanları hem de IgA anti gliadin değerlerinin yükselişi ile glutensiz diyete uyumsuz olduğu bilindiği dönemde büyüme hızı yavaşladı ve olgunun yaşa göre boy uzunluğu 2550. persentiller aralığında izlendi. İyi planlanmamış bir glutensiz diyet programı yüksek glisemik indeksi nedeniyle glisemik değişkenliği arttırarak; yetersizdengesiz makro ve mikro besin ögesi bileşimi nedeniyle de beslenme yetersizliğine neden olarak çocuğun büyüme hızını yavaşlatabilir (2). Olgumuzda büyüme hızının arttığı ergenlik döneminde glutensiz diyete uyumsuzluğun büyümeyi yavaşlatarak hedef boy uzunluğuna ulaşmassını engellemiş olabileceği düşünüldü. Bu nedenle tip 1 diyabet ve çölyak hastalığı birlikteliği olan olgular ve aileleri deneyimli bir diyetisyen tarafından yakından izlenmelidir. Özellikle biyolojik ve psikolojik değişimlerine neden olan ergenlik döneminde tip 1 diyabet ve çölyak hastalığı birlikteliğinde ergen, glutensiz diyete uyum sağlaması, dengeli beslenme davranışları edinmesi, doğru karbonhidrat sayımı uygulamaları yapması için hem aile hem de diyabet ekibi tarafindan desteklenmeli ve teşvik edilmelidir. 

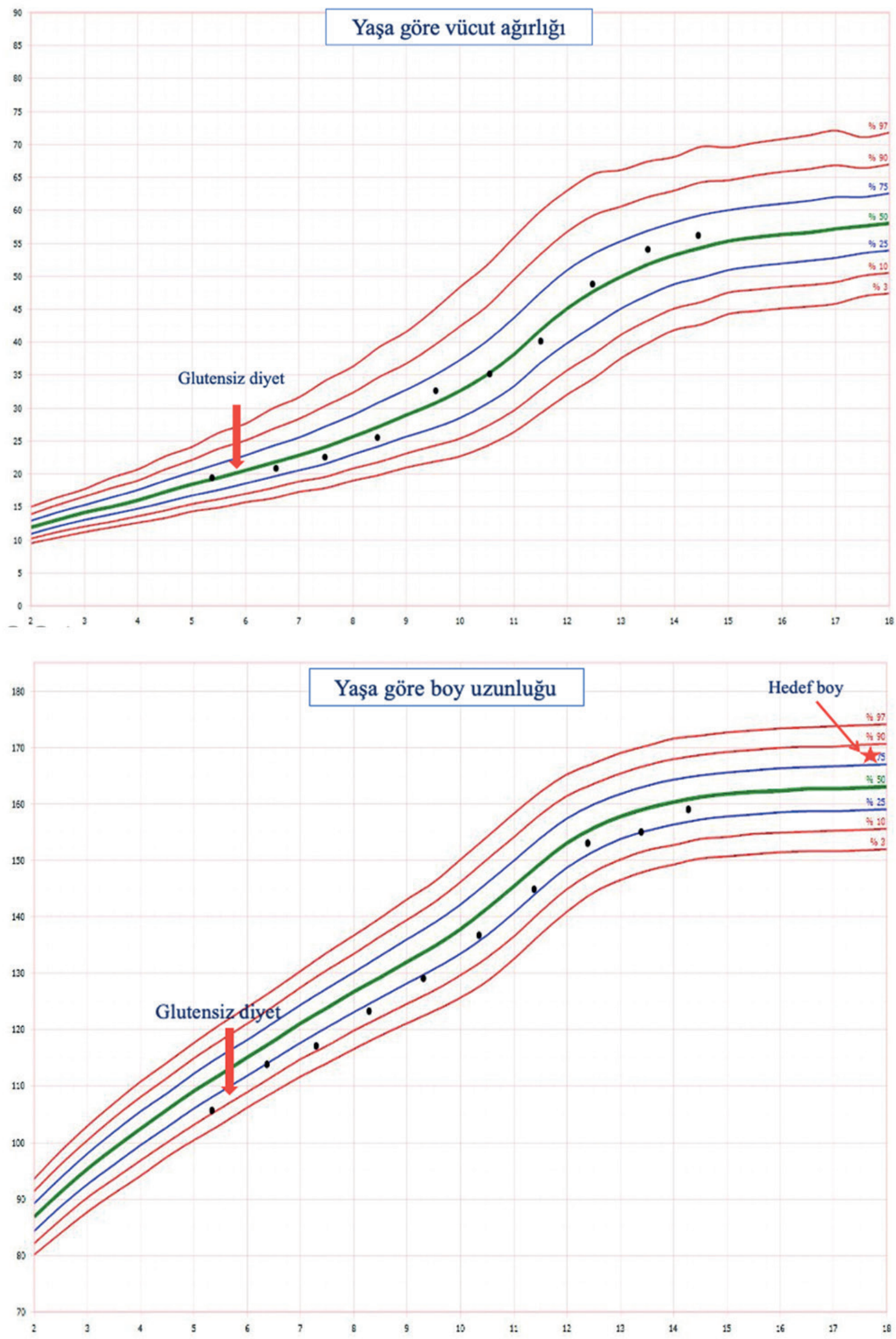

Şekil 3. Olgunun yaşa göre vücut ağırlığı ve yaşa göre boy uzunluğu persentil eğrileri (Neyzi, 2008) 
Sonuç olarak, tip 1 diyabet ve çölyak hastalığı birlikteliği olan olguların bireysel özellikleri, besin tüketim kayıtları, fiziksel aktivite günlükleri ve kan şekeri profili değerlendirilerek; tanı anında ailelere/ bakımda sorumlu kişilere, ergenliğe geçişte olgulara yeterli ve dengeli glutensiz diyet ve doğru karbonhidrat sayımı uygulamalarına dair danışmanlık olguya özgü sıklıkta yapılarak izlenmelidir.

Çıkar çatışması - Conflict of interest: Yazarlar çıkar çatışması olmadığını beyan ederler. - The authors declare that they have no conflict of interest.

\section{KAYNAKLAR}

1. Kurppa K, Laitinen A, Agardh D. Coeliac disease in children with type 1 diabetes. Lancet Child Adolesc Heal. 2018;2(2):133-43.

2. Craig ME, Prinz N, Boyle CT, Campbell FM, Jones TW, Hofer SE, et al. Prevalence of celiac disease in 52,721 youth with type 1diabetes: International comparison across three continents. Diabetes Care. 2017;40(8):103440.

3. Şimsek DG, Aycan Z, Özen S, Çetinkaya S, Kara C, Abali $\mathrm{S}$, et al. Diabetes care, glycemic control, complications, and concomitant autoimmune diseases in children with type 1 diabetes in Turkey: A multicenter study. J Clin Res Pediatr Endocrinol. 2013;5(1):20-6.

4. Mahmud FH, Elbarbary NS, Fröhlich-Reiterer E, Holl RW, Kordonouri O, Knip M, et al. ISPAD Clinical Practice Consensus Guidelines 2018: Other complications and associated conditions in children and adolescents with type 1 diabetes. Pediatr Diabetes. 2018;19(Suppl 27):27586.
5. Fröhlich-Reiterer EE, Kaspers S, Hofer S, Schober E, Kordonouri O, Pozza SBD, et al. Anthropometry, metabolic control, and follow-up in children and adolescents with type 1 diabetes mellitus and biopsyproven celiac disease. J Pediatr. 2011;158(4):589-93.

6. Rubio-Tapia A, Hill ID, Kelly CP, Calderwood AH, Murray JA. ACG Clinical Guidelines: Diagnosis and management of celiac disease. Am J Gastroenterol. 2013;108(5):65676.

7. Smart CE, Annan F, Higgins LA, Jelleryd E, Lopez M, Acerini CL. ISPAD Clinical Practice Consensus Guidelines 2018: Nutritional management in children and adolescents with diabetes. Pediatr Diabetes. 2018;19(Suppl 27):136-54.

8. Krupa-Kozak U, Lange E. The gluten-free diet and glycaemic index in the management of coeliac disease associated with type 1 diabetes. Food Rev Int. 2019;35(6):587-608.

9. Camarca M, Mozzillo E, Nugnes R, Zito E, Falco M, Fattorusso V, et al. Celiac disease in type 1 diabetes mellitus. Ital J Pediatr. 2012;38(1):10.

10. Capriles VD, Arêas JAG. Approaches to reduce the glycemic response of gluten-free products: In vivo and in vitro studies. Food Funct. 2016;7(3):1266-72.

11. Pham-Short A, Donaghue KC, Ambler G, Garnett S, Craig ME. Quality of life in type 1 diabetes and celiac disease: Role of the gluten-free diet. J Pediatr. 2016;179:131-8.

12. Sanchez-Albisua I, Wolf J, Neu A, Geiger H, Wäscher I, Stern M. Coeliac disease in children with type 1 diabetes mellitus: the effect of the gluten-free diet. Diabet Med. 2005;22:1079-82.

13. Neyzi O, Günöz H, Furman A, Bundak R, Gökçay G, Darendeliler F, et al. Türk çocuklarında vücut ağırlığı, boy uzunluğu, baş çevresi ve vücut kitle indeksi referans değerleri. Çocuk Sağlığı ve Hastalıkları Dergisi. 2008;51:1-14. 